\title{
Carbon and Nitrogen Mineralization Kinetics in Soil Previously Amended with Sewage Sludge
}

\begin{abstract}
Michael Boyle* and E. A. Paul
ABSTRACT

Microbial mineralization rates of organic carbon $(C)$ and nitrogen (N) were determined on the same sludge-amended and nonamended soil samples. The purpose of this integrated approach was to highlight the long-term dynamics of $\mathbf{N}$ release with $\boldsymbol{C}$ stabilization in sludge-affected soil. Three application rates of digested municipal sludge, check, $45 \mathrm{Mg} \mathrm{ha}^{-1}$ and $180 \mathrm{Mg} \mathrm{ha}^{-1}$, were incorporated into field plots annually for 8 years, with no addition during the subsequent 3 years. Barley was grown on the site each spring of the 11 years. In an 87-week laboratory incubation experiment conducted on soil samples collected 3 years after the last sludge addition, $\mathbf{N}$ and $C$ mineralization rates $\left(\boldsymbol{k}_{\mathrm{n}}, \boldsymbol{k}_{\mathrm{c}}\right)$ increased with sludge application rate. Soil nitrogen mineralization potentials $\left(N_{0}\right)$ increased with sludge application, unlike carbon mineralization potentials $\left(C_{0}\right)$ which did not correlate with sludge application. The $C / N$ ratio of the mineralized organic matter decreased with sludge application rate. Three years after field incorporation of sludge, decomposition of the organic fraction can be described as a set of two first-order rate reactions. One fraction is characterized by a large stable element (high $N_{\mathrm{o}} C_{\mathrm{o}}$ and low $k_{\mathrm{n}}, \boldsymbol{k}_{\mathrm{c}}$; the second fraction consists of a smaller labile

Michael Boyle, IPH, Harvard School of Public Health, Boston, MA 02115; and E.A. Paul, Dept. of Crop \& Soil Sciences, Michigan State Univ., East Lansing, MI 48824. Contribution from the Dept. of Plant \& Soil Biology, Univ. of California, Berkeley. Received 20 Jan. 1988. *Corresponding author.

Published in Soil Sci. Soc. Am. J. 53:99-103 (1989).

portion which is characterized by low $N_{\mathrm{o}}, C_{\mathrm{v}}$ and high $k_{\mathrm{n}}, k_{\mathrm{c}}$ values. The microbial biomass decreased to less than half of its original amount after 20 weeks of incubation in all soil treatments.

$T$ HE FORMATION of soil organic matter (SOM) is a reversible reaction. Additions of organic waste, such as municipal sludge, has been proposed as one method of maintaining levels of organic matter in agricultural as well as forested and disturbed lands. Data on $\mathrm{N}$ mineralization in soils that had recent applications of sludge (Epstein et al., 1978; Lindemann and Cardinas, 1984), as well as studies on land previously amended with sludge (Stark and Clapp, 1980; Griffin and Laine, 1983), have contributed to the understanding of soil $\mathbf{N}$ behavior with sludge additions. However there remains a need for models that predict sludge $\mathrm{N}$ release especially after the termination of application (Page et al., 1983). Because $\mathrm{N}$ turnover in soil is highly dependent on $\mathrm{C}$ transformations and microbial biomass (McGill et al., 1981), an integrated approach was taken in this study. A $\mathbf{N}$ mineralization indicator (accumulation of $\mathrm{NO}_{3}$ ), a $\mathrm{C}$ decomposition parameter $\left(\mathrm{CO}_{2}\right.$ evolution), and an estimate of microbial bio-
\end{abstract}


mass $\left(\mathrm{CHCl}_{3}\right.$ fumigation-incubation) were used to characterize the labile organic fraction while also identifying the interrelationship between $\mathrm{N}$ and $\mathrm{C}$ mineralization kinetics.

\section{MATERIALS AND METHODS}

The 2.4 by $3.0-\mathrm{m}$ sludge-amended field plots are located on the Oxford Tract at the University of California, Berkeley. The Tierra loam soil had an original CEC of $20.1 \mathrm{cmol}$ $\mathrm{kg}^{-1}$, a $\mathrm{pH}$ of 5.4 , and soil organic $\mathrm{C}$ content range of 7 to $10.2 \mathrm{~g} \mathrm{~kg}^{-1}$. The sludge, from the East Bay Municipal Utility District (Oakland, CA), had been anaerobically digested for $20 \mathrm{~d}$ then vacuum-filtered. The final product was a wet-cake slurry that contained $25 \%$ solids (Williams et al., 1984). Some chemical properties of the sludge are presented in Table 1 . Three application rates of the sludge (check, $45 \mathrm{Mg}$ sludge $\mathrm{ha}^{-1}, 180 \mathrm{Mg}$ sludge ha ${ }^{-1}$ ) were incorporated into triplicate plots annually for 8 consecutive years with no additions for the 3 subsequent years. A barley crop (Hordeum Vulgare L.) was grown on the site for each of the 11 years of the study.

\section{Laboratory Incubation Study}

Surface soils $(0-15 \mathrm{~cm})$ were sampled from two of the triplicated field plots, three years after the last sludge application. Field-moist soils ( $15 \mathrm{~g}$ oven-dried weight) were passed through a 4-mm sieve, then uniformly mixed with $15 \mathrm{~g}$ of Ottawa sand $(0.59-0.42 \mathrm{~mm})$ and placed in $0.05 \mathrm{~L}$ Buckner funnels. To remove any inorganic-N prior to incubation, half of the soil-sand samples were initially leached with 100 $\mathrm{mL}$ of $0.1 M \mathrm{CaCl}_{2}$ and $25 \mathrm{~mL}$ of $\mathrm{N}$-free nutrient solution (0.002 $M \mathrm{CaSO}_{4}, 0.002 \mathrm{M} \mathrm{MgSO}_{4}, 0.0025 M 0.0025 M$ $\mathrm{K}_{2} \mathrm{SO}_{4}$ ) according to Stanford and Smith (1972); these samples were then leached at week $3,6,11,17,21,27,38,50$, 66 , and 87 with $\mathrm{CaCl}_{2}$ and nutrient solution to determine the $\mathrm{N}$ mineralization rates. The $\mathrm{N}$ mineralization method of Stanford and Smith (1972) was modified by reducing the amount of leaching solution to $1 / 10$ of that recommended by the authors. This reduction in volume was intended to produce a less drastic perturbation, provide a concentrated solution for direct measurement and reduce the amount of organic $\mathrm{N}$ leached from the samples (Smith et al., 1980). The other half of the soil-sand samples were not leached but were maintained at constant weight throughout the 87-week incubation period by the addition of water. These nonleached samples were used as controls to determine the effect of $\mathrm{N}$ removal on $\mathrm{CO}_{2}$ evolution.

Into each air-tight Mason jar $(0.95 \mathrm{~L})$ which was fitted with a rubber septum, there were placed four 0.05-L Buckner funnels with glass filters and the soil-sand mixtures. Four

Table 1. A chemical analysis of the Oakland sludge (from Williams et al., 1980).

\begin{tabular}{lc} 
Sludge & $\begin{array}{c}\text { Concentration, } \mathrm{mg} \mathrm{kg}^{-1} \\
\text { dry wt }\end{array}$ \\
\hline Total N & 33000 \\
Ammonia & 2000 \\
Nitrate-N & 500 \\
Total P & 16400 \\
$\mathrm{Ca}$ & 22600 \\
$\mathrm{Mg}$ & 6200 \\
$\mathrm{~K}$ & 900 \\
$\mathrm{NA}$ & 1200 \\
$\mathrm{Cd}$ & 37 \\
$\mathrm{Cr}$ & 1470 \\
$\mathrm{Cu}$ & 600 \\
$\mathrm{Fe}$ & 22100 \\
$\mathrm{Hg}$ & 14 \\
$\mathrm{Mn}$ & 300 \\
$\mathrm{Ni}$ & 180 \\
$\mathrm{~Pb}$ & 1090 \\
$\mathrm{Zn}$ & 3910 \\
\hline
\end{tabular}

jars were filled with 16 funnels from each plot (two plots per sludge application rate), then incubated at $25^{\circ} \mathrm{C}$ for 87 weeks.

\section{Leachate Analysis}

At each sampling period the funnels were placed under constant vacuum until the soil-sand mixture reached the weight that corresponded to $-100 \mathrm{kPa}$ water potential $(60 \%$ water-holding capacity as determined by a hanging watercolumn method). Approximately $12.5 \mathrm{~mL}$ of the $\mathrm{CaCl}_{2}$ and nutrient solution was passed through the soil-sand mixture, and the leachate was frozen until the following order of analysis was performed: (a) $\mathrm{NH}_{4}-\mathrm{N}$; (b) $\mathrm{NO}_{2}-\mathrm{N}$; and (c) solubleC. Ammonium, $\mathrm{NO}_{2}$ plus $\mathrm{NO}_{3}$, and $\mathrm{NO}_{3}$ were determined on a flow-through injection system (Am. Public Health Assoc., 1981). Total soluble-C was determined using a Dohrmann DC 80 Carbon Analyzer which used a low temperature, persulfate-UV oxidation procedure.

\section{Soil Analysis}

All samples were triplicated and the results expressed on an oven-dried basis $\left(105^{\circ} \mathrm{C}\right)$. Total $\mathrm{C}$ determinations were performed on soils using a dry combustion technique (Nelson and Sommers, 1982) and the regular Kjeldahl method was performed for total soil $\mathrm{N}$ (Bremner and Mulvaney, 1982).

\section{$\mathrm{CO}_{2}$ Evolution}

Gas samples were obtained from the closed incubation jars by the use of a 1-mL syringe and then measured for $\mathrm{CO}_{2}$ concentration on a Varian Aerograph Model 920 gas chromatograph (GC). The jars were then opened and allowed to equilibrate with the atmosphere. The frequency of sampling ranged from daily to weekly to insure that the $\mathrm{CO}_{2}$ concentration did not exceed $0.8 \mathrm{~mol} \mathrm{~m}^{-3}$.

\section{Data Analysis}

A nonlinear least square (NLLS) regression analysis was used to calculate $N_{\mathrm{o}}, C_{\mathrm{o}}$, and associated rate constants from the 87-week data. The NLLS method was used to reduce the error imposed by the logarithmic transformation of low value mineralization data (Smith et al., 1980).

\section{Microbial Biomass C Determinations}

Biomass- $C$ was measured in these soil by the chloroform fumigation incubation method of Jenkinson and Powlson (1976). At week $0,3,6,21,38,50$, and 87 Buckner funnels containing the soil-sand mixture were removed from the incubation vessels (four funnels per sludge treatment) and transferred to glass beakers for fumigation with distilled $\mathrm{CHCl}_{3}$. The 10-day flush of $\mathrm{CO}_{2}$ after fumigation was measured on a gas chromatograph. Soil samples were not inoculated after fumigation nor were any controls subtracted from the $\mathrm{CO}_{2}$ evolution data (Voroney and Paul, 1984). The transfer of the soil-sand samples from the funnels to glass beakers was a precaution to prevent chloroform adsorbed on the plastic walls of the funnel from suppressing microbial activity and the flush of $\mathrm{CO}_{2}$ after fumigation.

\section{RESULTS AND DISCUSSION Nitrogen Mineralization}

The $\mathbf{N}$ mineralization rate, under a particular set of laboratory conditions, is proportional to the quantity of mineralizable substrate in soil (Stanford and Smith, 1972). Nitrogen mineralization potentials $\left(N_{0}\right)$ and $N$ mineralization rate coefficients $\left(k_{\mathrm{n}}\right)$ were calculated for each treatment (Table 2). These $N_{o}$ values determined 
Table 2. Soil $N$ and $\mathrm{C}$ mineralization potentials $\left(N_{\mathrm{o}}, C_{\mathrm{o}}\right)$ and rate constants $\left(k_{\mathrm{n}}, k_{\mathrm{c}}\right)$.

\begin{tabular}{|c|c|c|c|}
\hline & Check & $45 \mathrm{Mg} \mathrm{ha}^{-1}$ & $180 \mathrm{Mg} \mathrm{ha}^{-1}$ \\
\hline $\begin{array}{l}N_{\mathrm{o}}\left(\mathrm{mg} \mathrm{kg}^{-1}\right) \\
\mathrm{SE}^{*} \\
k_{\mathrm{n}}\left(\text { week }^{-1}\right) \\
C_{\mathrm{o}}\left(\mathrm{mg} \mathrm{kg}^{\prime \prime}\right) \\
\mathrm{SE} \\
k_{\mathrm{c}}\left(\text { week }^{-1}\right) \\
N_{\mathrm{o} /} / \mathbf{N}_{\text {tolal }}(\%) \\
C_{\mathrm{o}} / \mathrm{C}_{\text {toral }}(\%) \\
C_{\mathrm{c}} / N_{\mathrm{o}}\end{array}$ & $\begin{array}{c}191 \\
2 \\
0.010 \\
10010 \\
213 \\
0.005 \\
16.6 \\
67.6 \\
52.4\end{array}$ & $\begin{array}{c}427 \\
3 \\
0.013 \\
11983 \\
91 \\
0.007 \\
21.1 \\
55.2 \\
28.1\end{array}$ & $\begin{array}{c}579 \\
11 \\
0.020 \\
11933 \\
156 \\
0.011 \\
17.6 \\
36.2 \\
20.6\end{array}$ \\
\hline \multicolumn{4}{|c|}{ Sludge-soil mineralization data minus control } \\
\hline $\begin{array}{l}N_{\mathrm{o}}\left(\mathrm{mg} \mathrm{kg}^{-1}\right) \\
\mathrm{SE} \\
k_{\mathrm{n}}\left(\text { week }^{-1}\right) \\
C_{\mathrm{o}}\left(\mathrm{mg} \mathrm{kg}^{-1}\right) \\
\mathrm{SE} \\
k_{\mathrm{c}}\left(\text { week }^{-1}\right)\end{array}$ & & $\begin{array}{c}266 \\
2 \\
0.013 \\
5573 \\
321 \\
0.005\end{array}$ & $\begin{array}{c}458 \\
11 \\
0.020 \\
4723 \\
70 \\
0.019\end{array}$ \\
\hline
\end{tabular}

$* \mathrm{SE}=$ standard error of the mean.

by a NLLS analysis compared well with those reported for soils collected 2 and 4 years after sludge application (Stark and Clapp, 1980). The $k_{\mathrm{n}}$ values increased with sludge application rate but were less than those reported by Stark and Clapp (1980), Lindemann and Cardinas (1984), or Griffin and Laine (1983) because the incubation temperature was kept $10^{\circ} \mathrm{C}$ lower.

The increase in $k_{\mathrm{n}}$ values with an increase in sludge application rate was not due to a larger percentage of readily mineralizable $\mathrm{N}$ remaining after several years of field decomposition. Although $N_{\mathrm{o}}$ values were higher, the percentage of $N_{\mathrm{o}} / \mathrm{N}_{\text {total }}$ did not consistently increase with rate of sludge application (Table 2). Stark and Clapp (1980) reported similar $N_{\mathrm{o}} / N_{\text {total }}$ values for soils after 2 years of repeated sludge application. In another study by these same authors, soils which were collected 4 years after the last sludge application had a $N_{\mathrm{o}} / N_{\text {total }}$ value $12.1 \%$ vs. $19.5 \%$ for the control. It is assumed that after the termination of the sludge application $N_{\mathrm{o}}, k_{\mathrm{n}}$, and the percent of labile- $\mathrm{N}$ divided by total-N will decrease with increasing age of the site. Results from our experiment indicate that 3 years after the last sludge addition there still remains a substantial labile-N pool in the sludge-treated soils.

\section{Carbon Mineralization}

Periodic leaching of available $\mathrm{N}$ only slightly increased the rate of organic- $\mathrm{C}$ mineralization in the high sludge application rate as measured by $\mathrm{CO}_{2}$ evolution (Table 3). The results suggest that available-C and not $\mathrm{N}$ was probably limiting in the sludge-treated and the nontreated soils.

In order to quantify the $\mathrm{C}$ associated with the labile$\mathrm{N}$ fraction $\left(N_{\mathrm{o}}\right), \mathrm{C}$ mineralization potentials $\left(C_{\mathrm{o}}\right)$ were also calculated by the NLLS technique. Soluble-C leached from the soil represented $<3 \%$ of the $\mathrm{C}$ evolved as $\mathrm{CO}_{2}$ and was not included in computing $C_{\mathrm{o}}$. The $C_{\mathrm{o}}$, unlike $N_{\mathrm{o}}$, did not correlate with sludge additions. In fact, that portion of total soil $\mathrm{C}$ that comprised $C_{0}$ decreased with sludge application rate $(\mathrm{Ta}-$ ble 2). Although speculative, these results suggest that the total soil C left after 3 years of field decomposition was more recalcitrant than native soil organic-C. The characteristics of this $\mathrm{C}$ pool is represented by the sludge application data minus the controls in Table 2.
Table 3. The effect of multiple leaching on total soil carbon mineralization after the 87-week incubation.

\begin{tabular}{|c|c|c|}
\hline Treatment & Leached & Not leached \\
\hline & \multicolumn{2}{|c|}{$-\mathrm{mg} \mathrm{CO}_{2}-\mathrm{C} \mathrm{kg}^{-1}$ soil } \\
\hline Check & 3615.0 & 3753.5 \\
\hline $\mathrm{SE} \dagger$ & 547.9 & 338.1 \\
\hline $45 \mathrm{Mg} \mathrm{ha}^{-1}$ & 5822.5 & 5613.5 \\
\hline $\mathrm{SE}$ & 437.8 & 328.5 \\
\hline $180 \mathrm{Mg} \mathrm{ha}^{-1}$ & 8014.0 & 7009.5 \\
\hline SE & 506.2 & 453.0 \\
\hline
\end{tabular}

$\uparrow \mathrm{SE}=$ Standard error of the mean.

Stabilization is a term often used to describe soil organic matter in toto, but SOM is composed of many components, each varying in size, rate of decomposition, and proportion to the total organic pool. Although the high sludge application rate doubled the rate constant $\left(k_{\mathrm{c}}\right)$, the percentage of mineralizable-C to soil organic- $C$ decreased $\left(C_{\mathrm{o}} / C_{\text {total }}\right)$. The concept of organic matter stabilization should involve at least three levels of evaluation: the decay rate constant, the absolute size of the mineralizable pool, and the relative size of the "active" fraction.

\section{The Association Between $\mathbf{C}$ and $\mathbf{N}$ Mineralization}

The pool sizes and decay constants in Table 2 suggest that sludge stabilization within soil was more extensive for sludge-C than for sludge- $N$. These two essential parameters, depicted in Fig. 1 as cumulative mineralized $\mathrm{C}$ and $\mathrm{N}$, increased with sludge application rate. The similar shape of the $\log _{e}$ curves indicate that the $\mathrm{C} / \mathrm{N}$ ratio did not fluctuate over the 87-week incubation. The relationship between the amount of $\mathrm{N}$ mineralized per $\mathrm{CO}_{2}$-evolved was constant for each application rate and increased with sludge application (Fig. 2). Possible factors or combination of factors for the observed decomposition characteristics are:

1. the $\mathrm{C} / \mathrm{N}$ ratio of microbial byproducts from sludge decomposition was lower than that of the native soil organic fraction;

2. the $\mathrm{C}$ stabilized in sludge was primarily derived from anaerobically digested microbial cell walls which may be more recalcitrant than lignin-derived SOM;

3. components within the sludge could be inhibiting mineralization of $\mathrm{C}$ more so than $\mathrm{N}$; and/or

4. the labile sludge- $\mathrm{N}$ remained in the soil active fraction after the stabilization of sludge-C due to the excess incorporation of $\mathrm{N}$ into microbial biomass without a concurrent increase in biomassC.

\section{Curve Splitting}

As seen in Fig. 1, a single first-order function would not accurately describe the $\mathrm{N}$ or $\mathrm{C}$ mineralization behavior from initiation to completion of the incubation. More than one first-order equation is needed to reflect the heterogeneity of substrate quality. The use of a combination of first-order equations has been employed by Lindemann and Cardinas (1984) to describe sludge decomposition kinetics. To section the mineralization curves into two unique pools with their own rate constants, a curve-splitting technique was used (Paul and Voroney, 1980). The reason for seg- 


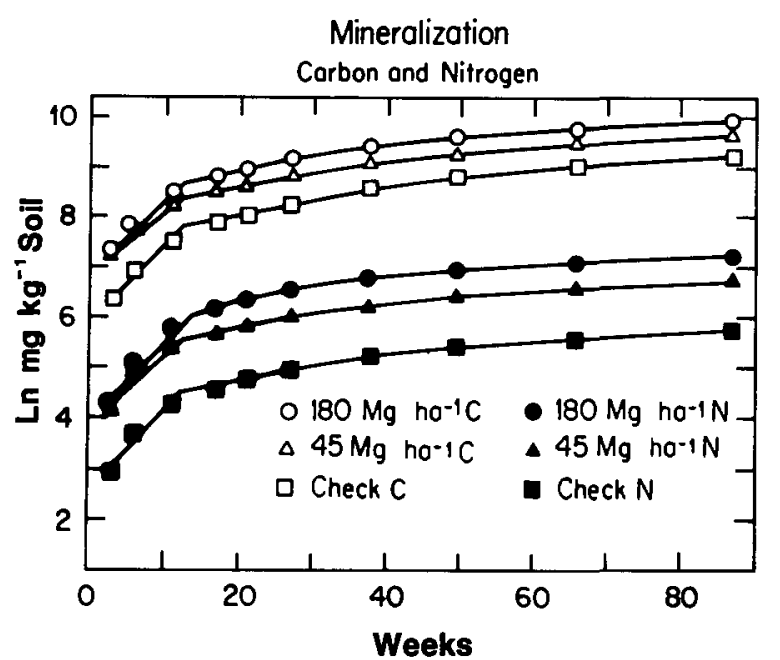

Fig. 1. The effect of sludge application rate on soil $\mathrm{C}$ and $\mathrm{N}$ mineralization.

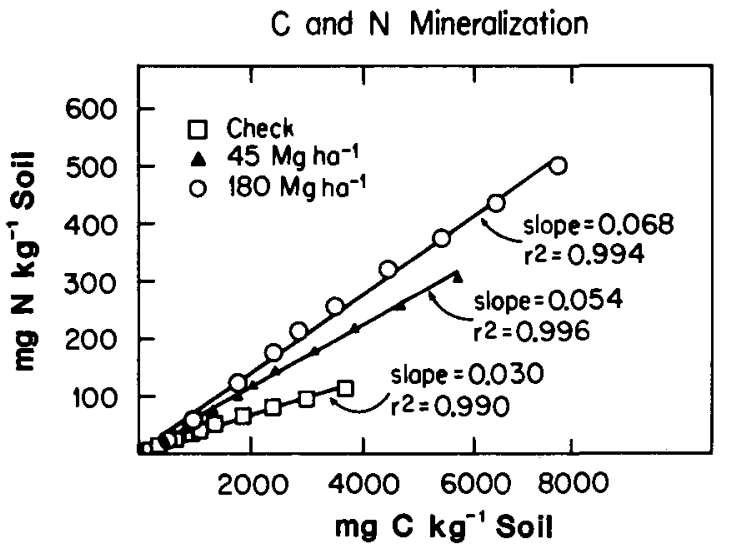

Fig. 2. The effect of sludge application rate on the amount of soil $\mathrm{N}$ mineralized as $\mathrm{NO}_{3}$ per unit soil $\mathrm{C}$ evolved as $\mathrm{CO}_{2}$.

menting the mineralization curves at 11 weeks can be seen in Fig. 1. The correlation coefficient $(r)$ values from linear regression analysis produces the largest combined $r$ value for all curves when segmented at 11 weeks, except for $\mathrm{N}$ with the highest sludge application. The split that gave the highest combined $r$ value for this treatment was at the next sampling date, 17 weeks, suggesting that the high-sludge application prolonged the rapid $\mathrm{N}$ mineralization portion of the curve.

To separate out the first 11-week pool sizes of both $\mathrm{C}$ and $\mathrm{N}$, the 11-week mineralization data were subtracted out from the original $N_{\mathrm{o}}$ and $C_{\mathrm{o}}$ estimates. Pool sizes were recalculated by NLLS analysis which gave long-term pool sizes for the period between week 11 and week $87\left[N_{\mathrm{o}(11-87)}, C_{\mathrm{o}(11-87)}\right]$. These long-term pool sizes were then subtracted from the original $C_{\mathrm{o}}$ and $N_{\mathrm{o}}$ estimates to get the short-term pools (first 11 weeks). To determine the short-term rate constants $\left[k_{\mathrm{n}(0-1)}\right.$ or $\left.k_{\mathrm{c}(0-11)}\right]$, a linear regression was performed on the $\log _{e}$ of three values which represent the difference of the mineralized $\mathrm{N}$ or $\mathrm{C}$ accumulated in the first 11 weeks $\left[N_{\mathrm{o}(0-11)}, C_{\mathrm{o}(0-11)}\right.$ from the newly calculated $N_{\mathrm{o}(0-11)}$ and $C_{\text {o(0-11). }}$. The rate constant $k_{\text {n }(0-11)}$ for the check soil is represented by the slope of the bottom curve in Fig. 3. In the same graph, the $y$ intercept of the top line represents the $\log _{e}$ of the long-term pool size $\left[N_{\mathrm{o}(11-}\right.$ 87)] for the check soil. In Table 4, the original pool

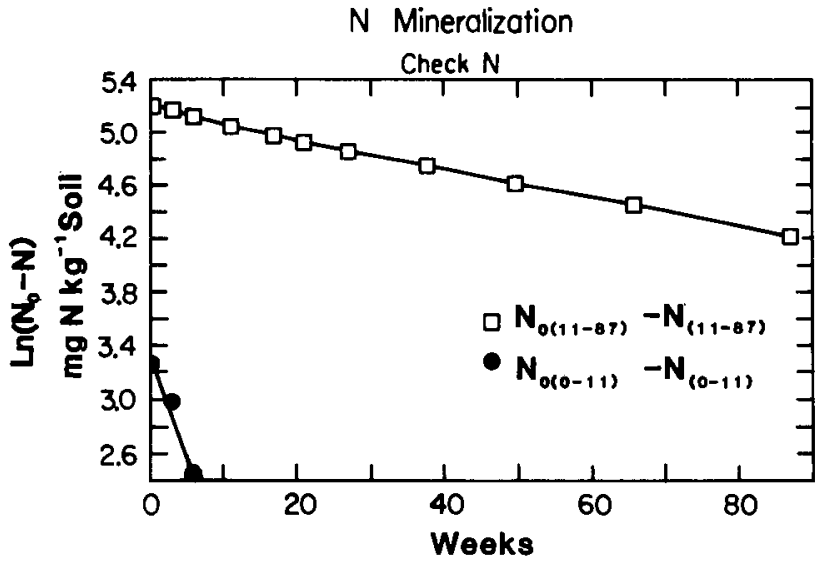

Fig. 3. The use of curve-splitting techniques to segment the check $\mathrm{N}$ mineralization data into two distinct rate functions with appropriate pool sizes $\left[N_{\text {o(0-11) }}, N_{\text {o(11-87) }}\right]$ and rate constants $\left[k_{\text {n(0-11), }}\right.$ $\boldsymbol{k}_{\mathrm{n}(11-87)]}$.

sizes and rate constants are represented as a two components system for each treatment.

\section{Microbial Biomass}

Soil microflora contain substantial quantities of $\mathrm{C}$ and $\mathrm{N}$, which upon death are readily mineralized by the surviving microorganisms (Jenkinson and Powlson, 1976; Anderson and Domsch, 1980). In a field study, Lynch and Panting (1980) observed a biomass size fluctuation in an agricultural soil that represented from 1.1 to $2.7 \%$ of the total soil C over the course of 1 year. Robertson et al. (1988) attributed $20 \%$ of mineralized $\mathrm{C}$ to microbial biomass decline in the first 12 weeks of soil incubation. The size of the soil microbial biomass as effected by sludge application over the course of the 87-week incubation is represented in Table 5 . The biomass size was initially higher in the sludge-amended soil than the checks but did not consistently increase with application rate. The average decline in the biomass-C decreased to half of its original pool size after 21 weeks.

The decline of all soil treatments can be described by a first-order equation for the first 50 weeks of incubation (each point in Fig. 4 represents an average of 12 measurements). The linear regression of the average $\log _{e}$ values of biomass-C per time produced a coefficient of determination $\left(r^{2}\right)$ of 0.90 with a slope of -0.06 week $^{-1}$. Such a decay rate would produce a turnover time, assuming that growth rate was small compared to the death rate, of 16.7 weeks for the first 50 weeks of incubation. The microbial pool of both $\mathrm{C}$ and $\mathrm{N}$ contributes a small but labile fraction to the mineralizable organic component during this initial period.

The size of the microbial population did not appear to be a limiting factor to decomposition after the initial days of incubation, in light of the observed decrease in microbial biomass time. The biomass size was relatively stable and appeared to achieve steady state after $50 \mathrm{wk}$.

Although no biomass $\mathrm{N}$ measurements were performed during the incubation, the soil microbial biomass $\mathrm{C} / \mathrm{N}$ ratio were determined initially (Boyle and Paul, 1989). Assuming a biomass $\mathrm{C} / \mathrm{N}$ ratio of 4.8 for the control soil and 3.9 for the high sludge application 
Table 4. Soil $\mathrm{C}$ and $\mathrm{N}$ mineralization data segmented into two firstorder rate equations.

\begin{tabular}{lccc}
\hline & Check & $45 \mathrm{Mg} \mathrm{ha}^{-1}$ & $180 \mathrm{Mg} \mathrm{ha}^{-1}$ \\
\hline$N_{\text {o(10-11) }}\left(\mathrm{mg} \mathrm{kg}^{-1}\right)$ & 26 & 83 & 128 \\
$k_{\text {o(0-1) }}\left(\right.$ week $\left.^{-1}\right)$ & 0.073 & 0.170 & 0.112 \\
$C_{\text {o(0-11) }}\left(\mathrm{mg} \mathrm{kg}^{-1}\right)$ & 667 & 1351 & 1821 \\
$k_{\text {c(0-11) }}\left(\right.$ week $\left.^{-1}\right)$ & 0.137 & 0.170 & 0.137 \\
$N_{\text {o(11-87) }}\left(\mathrm{mg} \mathrm{kg}^{-1}\right)$ & 175 & 417 & 613 \\
$k_{\text {n(11-87) }}\left(\right.$ week $\left.^{-1}\right)$ & 0.011 & 0.013 & 0.017 \\
$C_{\text {o(1-11-87) }}\left(\mathrm{mg} \mathrm{kg}^{-1}\right)$ & 11975 & 11488 & 11368 \\
$k_{\text {c(11-87) }}\left(\right.$ week $\left.^{-1}\right)$ & 0.004 & 0.007 & 0.011 \\
\hline
\end{tabular}

Table 5. Microbial biomass $C$ content in the sludge-amended and nonamended soils over the length of the 87-week incubation. $\dagger$

\begin{tabular}{lrrrrrrr}
\hline & \multicolumn{7}{c}{ Weeks } \\
\cline { 2 - 8 } Treatment & \multicolumn{1}{c}{0} & \multicolumn{1}{c}{3} & \multicolumn{1}{c}{6} & \multicolumn{1}{c}{21} & \multicolumn{1}{c}{38} & \multicolumn{1}{c}{50} & 87 \\
\cline { 2 - 8 } & \multicolumn{7}{c}{$\mathrm{mg} \mathrm{C} \mathrm{kg}^{-1}$} \\
Check & 253.0 & 195.0 & 283.0 & 135.0 & 140.0 & 116.0 & 136.0 \\
$\mathrm{SE} \neq$ & 10.6 & 9.1 & 4.8 & 4.5 & 13.7 & 9.9 & 17.6 \\
$45 \mathrm{Mg} \mathrm{ha}^{-1}$ & 419.0 & 257.0 & 318.0 & 157.0 & 189.0 & 145.0 & 154.0 \\
$\mathrm{SE}$ & 27.3 & 10.0 & 16.3 & 3.6 & 12.8 & 13.2 & 11.8 \\
$180 \mathrm{Mg} \mathrm{ha}^{-1}$ & 409.0 & 312.0 & 345.0 & 225.0 & 153.0 & 124.0 & 147.0 \\
$\mathrm{SE}$ & 84.4 & 14.1 & 6.0 & 10.9 & 16.1 & 13.9 & 23.6 \\
\hline
\end{tabular}

† Biomass $\mathrm{C}=(10$ day $) \mathrm{CO}_{2}-\mathrm{C} / 0.45$.

$\ddagger \mathrm{SE}=$ standard error of the mean of 4 replicates.

Biomass Carbon

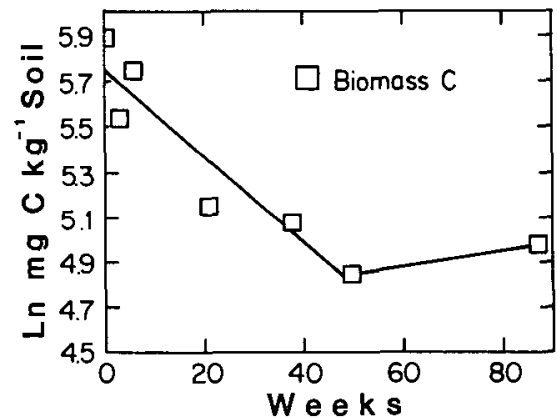

Fig. 4. The effect of incubation time on soil microbial biomass carbon (averaged of the three sludge treatments).

rate, the declining biomass could contribute $47 \%$ of the mineralized $\mathrm{N}$ for the control soil and $18 \%$ for the high sludge amended rate in the first 21 weeks of incubation.

\section{SUMMARY AND CONCLUSIONS}

The $\mathrm{N}$ mineralization potentials $\left(N_{\mathrm{o}}\right)$ were greater in sludge-amended soils 3 years after the last sludge addition than in the control soils. The highest sludge application contained the most labile organic $\mathrm{N}$ fraction (largest rate constant). The first-order rate constant $\left(k_{\mathrm{n}}\right)$ increased with increased initial substrate concentrations $\left(N_{\mathrm{o}}\right)$ and decreased with incubation time, indicating that one first-order equation may not adequately describe long-term organic matter mineralization in these soils.

Carbon mineralization potentials $\left(C_{\mathrm{o}}\right)$ did not correspond with sludge application rate. The $C_{\mathrm{o}} / C_{\text {total }}$ values decreased with increased sludge application rate, suggesting that the sludge $C$ that remained in soil after deposition had a larger stable pool than $\mathrm{C}$ in the control plots.

The $\mathrm{C} / \mathrm{N}$ ratios of the mineralizable organic fraction decreased with increased sludge application rate, in- dicating that the soil-sludge $\mathrm{C}$ may be more stable than the corresponding $\mathrm{N}$ fraction.

With the use of NLLS regression analysis and curvesplitting techniques, the mineralization of both $C$ and $\mathrm{N}$ can be described as consisting of a labile short-term pool (first 11 weeks) and a slower decaying organic reservoir (between 11 and 87 weeks).

In all soil treatments, soil microbial biomass decreased to less than half of its original size after 20 weeks of incubation and stabilized after week 50 .

\section{ACKNOWLEDGMENTS}

The work was performed at the Dept. of Plant and Soil Biology, Univ. of California, Berkeley, with support from the Western Regional Project W-170.

\section{REFERENCES}

American Public Health Association. 1980. Standard methods for examination of water and wastewater. 1981. 15th ed. Am. Public Health Assoc, Washington, DC.

Anderson, J.P.E., and K.H. Domsch. 1980. Quantities of plant nutrients in the microbial biomass of selected soils. Soil Sci., 130:211216.

Bremner, J.M., and C.S. Mulvaney. 1982. Nitrogen-total. In A.L. Page et al. (ed.) Methods of soil analysis. Part 2. 2nd ed. Agronomy 9:595-624.

Boyle, M.A., and E.A. Paul. 1989. Nitrogen transformations in soils previously amended with sewage sludge. Soil Sci. Soc. Am. J. (in press).

Epstein, E., D.D. Keane, J.J. Meisinger, and J.O. Legg. 1978. Mineralization of nitrogen from sewage sludge and sewage sludge compost. J. Environ. Qual. 7:217-221.

Griffin, G.F., and A.F. Laine. 1983. Nitrogen mineralization in soils previously amended with organic wastes. Agron. J. 75:124-129.

Jenkinson, D.S., and D.S. Powlson. 1976. The effect of biocidal treatments on metabolism in soil. V. A method for measuring soil biomass. Soil Biol. Biochem. 8:209-213.

Lindemann, W.C., and M. Cardenas. 1984. Nitrogen mineralization potential and nitrogen transformations of sludge-amended soil. Soil Sci. Soc. Am. J. 48:1072-1077.

Lynch, J.M., and L.M. Panting. 1980. Cultivation and the soil biomass. Soil Biol. Biochem. 12:29-33.

McGill, W.B., H.W. Hunt, R.G. Woodmansee and J.O. Reuss. 1981 Phoenix - a model of the dynamics of carbon and nitrogen in grassland soils. p. 237-249. In F.E. Clark and T. Rosswall (ed.) Terrestrial nitrogen cycles: Processes, ecosystem strategies and management impact. Ecol. Bull. 33.

Nelson, D.W., and L.E. Sommers. 1982. Total carbon, organic carbon, organic matter. In A.L. Page et al. (ed.) Methods of soil analysis. Part 2. 2nd ed. Agronomy 9:539-579.

Page, A.L., T.L. Gleason, III, J.E. Smith, Jr., I.K. Iskandar, and L.E. Sommers (ed.) 1983. Utilization of municipal wastewater and sludge on land. Proc., Denver, CO, 23-25 Feb. 1983, Univ. of California, Riverside.

Paul, E.A., and R.P. Voroney. 1980. Nutrient and energy flows through microbial biomass. p. 215-237. In D.C. Ellwood (ed.) Contemporary microbial ecology. Academic Press, London.

Robertson, K., J. Schnurer, M. Clarholm, T.A. Bonde, and T. Rosswell. 1988. Microbial biomass in relation to $\mathrm{C}$ and $\mathrm{N}$ mineralization during laboratory incubations. Soil Biol. Biochem. 20:281286.

Smith, J.L. R.R. Schnabel, B.L. McNeal, and G.S. Campbell, 1980 Potential errors in first-order model for estimating soil nitrogen mineralization potentials. Soil Sci. Soc. Am. J. 44:996-1000.

Stanford, G., and S.J. Smith. 1972. Nitrogen mineralization potentials of soils. Soil Sci. Soc. Am. J. 36:465-472.

Stark, S.A., and C.E. Clapp. 1980. Residual nitrogen availability from soils treated with sewage sludge in a field experiment. $J$. Environ. Qual. 9:505-512.

Voroney, R.P., and E.A. Paul. 1984. Determination of $K_{\mathrm{c}}$ and $K_{\mathrm{n}}$ in situ for calibration of the chloroform fumigation-incubation method. Soil Biol. Biochem. 16:9-14.

Williams, D.E., J. Vlamis, A.H. Pukite, and J.E. Corey. 1980. Trace element accumulation, movement and distribution in the soil profile after massive application of sewage sludge. Soil Sci. 129:119-132.

Williams, D.E., J. Vlamis, A.H. Pukite, and J.E. Corey. 1984. Metal movement in sludge-treated soils after six years of sludge additions. I. Cadmium, copper, lead and zinc. Soil Sci. 137:351-359. 